\title{
Decentralization reforms and their relations to local democracy and efficiency: CEE lessons
}

UDK: $353(497.4): 35$

\author{
Juraj Nemec \\ Matej Bel University Banska Bystrica, Slovakia \\ juraj.nemec@umb.sk
}

\begin{abstract}
The paper discusses the implementation of decentralization in Central and Eastern Europe Countries after the signature and ratification of the European Charter of Local Self-Government. Decentralization as one of the reform approaches has several positive impacts on governance, but might have negative consequences, too. There are issues concerning allocation of financial resources, optimal territorial structure, weak local democracy. Local government units, especially the smaller ones, are not cost effective neither in administration nor in managing quality and expenditure of public services. For the reforms to realise the necessary democracy and efficiency, the author proposes to respect some principles of implementing decentralization.
\end{abstract}

Key words: local government, decentralization, democracy, efficiency, costs

\section{Introduction}

The creation of modern, democratic and effective local/regional selfgovernment system is still one of the main issues of public administration reforms in Central and Eastern Europe (CEE), although the basic legal and financial basis for local self-governments was created in most of CEE countries (especially in all accession countries) very soon.

Already in 1990, in countries like Czech Republic, Poland, Hungary, Slovakia the first local democratic elections were held. There was a set of new laws on local self-government, respecting basic criteria for this level of governance, as defined by the European Charter of Local Self-Government in following way: 


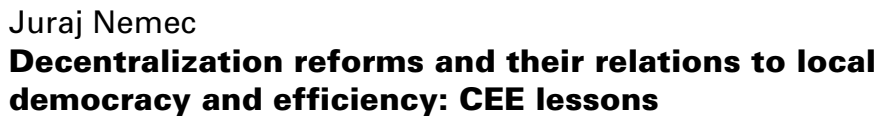

"Local self-government denotes the right and the ability of local authorities, within the limits of the law, to regulate and manage a substantial share of public affairs under their own responsibility and in the interests of the local population. ... The basic powers and responsibilities of local authorities shall be prescribed by the constitution or by statute. However, this provision shall not prevent the attribution to local authorities of powers and responsibilities for specific purposes in accordance with the law. ... Local authorities shall, within the limits of the law, have full discretion to exercise their initiative with regard to any matter, which is not excluded from their competence nor assigned to any other authority".

Other CEE countries, with some minor exceptions (like Ukraine, where local self- governments are still more formal than real force) followed similar patterns in later years, and as of today, the existence of local and in most cases also of regional self-government, allocated by many own responsibilities and also own resources is almost the rule in the region.

However, experience and especially outcomes show that not all positive expectations from decentralization and creation of local self-governing structures were fulfilled, on the contrary, region specific problems emerged. The paper highlights selected aspects of this issue.

\section{Decentralization - theoretical and practical issues}

\subsection{Decentralization - basic theory}

"Public responsibilities shall generally be exercised, in preference, by those authorities, which are closest to the citizen. Allocation of responsibility to another authority should weigh up the extent and nature of the task and requirements of efficiency and economy".

European Charter of Local Self-Government

As already mentioned, decentralization represents one of basic and almost universally used reform approaches. With some simplification it represents the transfer of powers, responsibilities and resources from central to 
lover level, from the state administration to self-government on macro-level, but also changes in systems of management of organizational units producing public services on micro-level (in the paper, we will not consider this second dimension).

Probably the most important issue behind decentralization is "the subsidiary" principle, clearly expressed by the European Charter of Local SelfGovernment, quoted above. The principle of subsidiarity conveys that public administration should operate on the lowest possible level, to achieve optimum quality. Closer to citizen it is expected that administrators and managers can better understand specific local needs and are able better to react to them. "Decentralization as the co-ordination mechanism for the public provision of goods and services represents an attempt to overcome information weaknesses involved in central co-ordination. When there is intergovernmental collaboration, then principals placed lower down know better how public programmes can be made to run efficiently" (Lane, 2000, p. 205).

From the economic point of view, following "effectiveness" principle of the EU White Paper (European Commission, 2001): "Decentralization ... is generally desirable from the viewpoint of efficiency and local accountability. These criteria must be balanced with other elements, such as spatial externalities, economies of scale, overall fiscal efficiency, regional equity, redistributive responsibilities of the government." (Allen and Tommasi, 2001, pp. 73-74).

From the point of view of other European good governance principles, decentralization has potential of positive impacts in more or less all governance dimensions. Especially openness and participation might be increased via effective decentralization, because of motivation, resulting from delegation of responsibilities and powers to lower level, closer to "customers", frequently level, where services are directly produced, and impacts better visible. However, such impacts might significantly decrease with the growing size of decentralized units (Westerwelt, H.W., 1994).

Based on these facts, decentralization is generally accepted as the important/main public administration reform in any country. However, it shall be stressed that decentralization is the tool with important potential, but also with some limitations. As there are not just positive reform mechanisms, also decentralization has to be introduced with respect to concrete reform environment, to avoid "unexpected" negative consequences of its implementation. 


\section{Juraj Nemec \\ Decentralization reforms and their relations to local \\ democracy and efficiency: CEE lessons}

Decentralization may for example increase direct and indirect costs. Economic theories suggest that many public services are connected with decreasing average costs with growing scale of their delivery, at least to some extent, because of better use of fixed assets (Stiglitz, 1989). Except of costs, decentralization may be limited by insufficient local capacities - too small government units are expected to suffer from lack of competence and expertise, but also from lack of resources. "The administrative capacity of subnational governments, and the administrative and compliance costs of decentralization must be taken into the account when assigning expenditure among levels of government" (Allen and Tommasi, 2001, p. 74).

Expected positive impacts of decentralization might be reversed also by so called transaction costs. Increased local activity means more voices, sometimes contradicting each other - it could be hardly expected that there is any government intervention with only positive impacts to all affected. To handle large scale of different interests is not simple, as well-known, ideal mechanism of collective voting does not exist in reality (Bailey, 1999).

With this, decentralization represents important, but to some extent controversial tool of public administration reform also in standard conditions of functional democracy. However, additional risks and limits of decentralization in a specific environment of CEE accession countries shall not be forgotten as indicated, during decentralization processes in CEE countries most of necessary new important formal structures were created, but for many reasons the public administration systems still do not function as expected. Impact and outcomes of reforms are in many cases not as anticipated, proving the fact that adoption of more or less effective "western" reform tools into the transitional environment is really complicated, and their non-careful implementation may lead to important problems (Coombes - Verheijen,1997), because of specific local environment.

Decentralization and the principle of subsidiarity are very much based on the assumption that they would further revive local democracy and stipulate a higher level of participation of citizen in local issues. However, this relation is "both-sides" relation. Decentralization may help to create modern governance system, based on "White Paper" principles, but its implementation has to respect the level, to which principles of openness, participation, accountability, effectiveness and coherence have been already achieved, too. 
Current "quality" of local democracy in CEE countries differs in many aspects from what is the reality in developed countries, and this fact shall be respected in the processes of decentralization and fiscal decentralization. Central governments argue that they are not willing to transfer additional resources to local authorities, because of macroeconomic consequences, but also because the local environment is not well developed to manage these resources. In the following chapters we provide some facts concerning this issue, using available data from selected CEE countries.

\subsection{Decentralization from practical point of view}

Decentralization in CEE region is based also on practical reasons. The most important of them is the EU public finance system. The Table 1 shows that large proportion of EU resources is used via structural and pre-accession funds, allocated mainly on regional principle.

Table 1: EU expenditures 2005 and 2006

\begin{tabular}{|l|r|r|c|}
\hline Chapter & \multicolumn{1}{|c|}{2006} & \multicolumn{1}{c|}{2005} & Change (\%) \\
\hline 1. Agriculture & 50991020000 & 48464850000 & $+5,21$ \\
2. Structural expenditures & 35639599237 & 32396027704 & $+10,01$ \\
3. Internal measures & 8889218143 & 8016662269 & $+10,88$ \\
4. External measures & 5369049920 & 5476162603 & $-1,96$ \\
5. Administration & 6656369817 & 6292367368 & $+5,78$ \\
6. Reserves & 458000000 & 446000000 & $+2,69$ \\
7. Pre-accession strategies & 2892850000 & 3286990000 & $-11,99$ \\
8. Equalization & 1073500332 & 1304988996 & $-17,74$ \\
\hline Total & 111969607449 & 105684048940 & $+5,95$ \\
\hline
\end{tabular}

Source: http://europa.eu.int/eur-lex/budget/data/D2006_VOL1/SK/nmc-grseq429609358303/index.html 


\section{Juraj Nemec \\ Decentralization reforms and their relations to local \\ democracy and efficiency: CEE lessons}

To become eligible to use structural funds any EU member state must draft its National Development Plan, based on thematic areas given by the European Commission (EC) and especially on own needs and priorities. Draft Plan is discussed with EC and after its approval national and regional bodies realize its implementation. The implementation is based on the NUTS system ("Nomenclature of territorial units for statistics"), including the following levels:

1. NUTS 0,1 - the country

2. NUTS 2 - regions with approximately 1-2 million inhabitants

3. NUTS 3 - lover regional tier

4. NUTS 4 - local units (micro regions)

5. NUTS 5 - municipalities

The existence of necessary effective regional structures, especially at NUTS 2 level is thus a pre-condition for the use of allocated funds. Regions shall be able to draft their regional development plans, decide on spending priorities; define programmes and select projects, constituted preferably in the form of self-governing units.

\subsection{Fiscal decentralization and its main problems}

Fiscal aspects represent a crucial part of the decentralisation process, as indicated also by the European Charter of Local Self-Government in following way:

"Local authorities shall be entitled, within national economic policy, to adequate financial resources of their own, of which they may dispose freely within the framework of their powers". ... Local authorities' financial resources shall be commensurate with the responsibilities provided for by the constitution and the law. Part at least of the financial resources of local authorities shall derive from local taxes and charges of which, within the limits of statute, they have the power to determine the rate. ... As far as possible, grants to local authorities shall not be earmarked for the financing of specific projects. The provision of grants shall not remove the basic freedom of local authorities to exercise policy discretion within their own jurisdiction". 


\section{Decentralization reforms and their remec democracy and efficiency: CEE lessons}

The definitions provided by the "Charter" highlight as minimum two important dimensions of the fiscal decentralisation, and raise also several issues, including those put bellow:

1. The necessity to establish an effective link between the scale of responsibilities of the local authorities and their financial basis.

2. The preference to finance local needs from local resources, and not by transfers (especially earmarked grants).

3. To what extent the state administration has the right to set predefined standards for the delivery of local public services?

\section{Fiscal decentralization resource transfer}

The experience shows that it is much simpler to define responsibilities to be transferred from the state to self-government authorities, than to define the amount of resources to be transferred to local authorities to finance the provision of re-allocated responsibilities.

According to our knowledge current systems of government budgeting and accounting in CEE do not allow to calculate full costs of provision of public services by the state (cash budgeting, economic classification of costs and non-accrual accounting methods are used, and changes to this have been introduced only recently).

As there are no adequate "service costs" data available, "negotiations" between local authorities and the state on the adequate amount of additional resources cannot be based on objective data, thus they become more or less political discussions, where more powerful partner wins. Risks of such processes, especially on the side of citizen, are tremendous.

\section{Increasing own sources of self-government}

The objective to finance local services from local resources and not by transfers from central budgets is to be respected, but it creates also certain additional problems. As the proportion of central government grants was still too high in many CEE countries in the end of the last century (Sevic, 2005), financial mechanisms shall change. With this at least four questions arise:

A. How to design the best appropriate intergovernmental fiscal system that will guarantee needed local revenues, especially if it is impossible to predict exact real incomes from local taxes, fees and other sources of local authorities' revenues? 


\section{Juraj Nemec \\ Decentralization reforms and their relations to local \\ democracy and efficiency: CEE lessons}

B. What is the appropriate system of management of local taxation?

C. Should we react to territorial disparities, created by fiscal decentralisation between regions and municipalities because of different tax base and different expenditure needs?

D. Municipal borrowing and its regulation.

As for the first question - also in the case we would know the exact amount of resources that shall be re-allocated to local authorities, there is no way to adjust the fiscal system in the country to produce exactly what is expected. We have just to respect this, and incorporate this limitation into the decision-making procedures.

Concerning the second question, there is a comprehensive discussion on the issue of the system of collection of taxes. There is no doubt that cen$\mathrm{tral} / \mathrm{mass}$ scale collection of taxes is more cost-effective. There are not enough reliable data on administrative and compliance costs of taxation from CEE conditions, but we can provide one example of recent research to highlight the problem.

Administrative costs of local taxation in the Czech Republic were calculated by Vitek and Pubal (2002) on the example of random sample of several municipalities, using methods of personal interviews, personal time-shots and analysis of existing statistical data. The Table 2 shows the results.

Table 2: Administrative costs of taxation in selected Czech municipalities (2000)

\begin{tabular}{|c|c|c|c|c|}
\hline Municipality & $\begin{array}{c}\text { Number of in- } \\
\text { habitants }\end{array}$ & $\begin{array}{c}\text { Revenue from } \\
\text { local taxes } \\
\text { (in 1000 CZK) }\end{array}$ & $\begin{array}{c}\text { Administrative } \\
\text { costs } \\
\text { (in 1000 CZK) }\end{array}$ & $\begin{array}{c}\text { Administrative } \\
\text { costs (\%) }\end{array}$ \\
\hline A & 150 & 3 & 6 & 200 \\
B & 400 & 7,5 & 8,1 & 107,5 \\
C & 6400 & 1313 & 182 & 13,9 \\
D & 9800 & 970 & 307 & 31,6 \\
E & 23000 & 1365 & 243 & 17,8 \\
F & 33100 & 7750 & 243 & 3,13 \\
G & 72000 & 15207 & 486 & 3,2 \\
\hline
\end{tabular}

Source: Vitek and Pubal, 2002 


\section{Decentralization reforms and their remec democracy and efficiency: CEE lessons}

Although the data have been obtained from just random sample with a small number of municipalities, and the calculation might be biased by problems to calculate exact costs (like estimate of proportion of time of some officials, devoted to this issue), figures clearly present the problem of relatively high administrative costs for any activity in too small municipalities (administrative costs of central taxation in the Czech Republic are estimated to be a bit less than $3 \%)$.

Concerning the third question more answers/solutions are available. Representatives of "right wing" theories would call for "voting by foot" (Hamernikova and Kubatova, 2005), but such "solutions" are not accepted in the system of European values. The Charter of European Local Self-Government provides its opinion to this in the following way:

"The protection of financially weaker local authorities calls for the institution of financial equalisation procedures or equivalent measures, which are designed to correct the effects of the unequal distribution of potential sources of finance and of the financial burden they must support. Such procedures or measures shall not diminish the discretion local authorities may exercise within their own sphere of responsibility. Local authorities shall be consulted, in an appropriate manner, on the way in which redistributed resources are to be allocated to them".

Equalisation on the base of different tax base and different expenditure needs is a standard tool in developed countries; however, effective equalisations systems have not been designed and approved in almost any of CEE countries, yet.

The last issue we discuss in this part is municipal borrowing. The "European Charter of Local Self-Government" provides following:

"For the purpose of borrowing for capital investment, local authorities shall have access to the national capital market within the limits of the law".

The real situation in CEE countries in the area of municipal borrowing is different. At the start in several countries originally there were no restrictions concerning the level and structure of external resources to be used to finance municipal financial needs. As the result, several municipalities accepted too high level of credits, and used borrowing to finance non-capital expenditures 


\section{Juraj Nemec \\ Decentralization reforms and their relations to local \\ democracy and efficiency: CEE lessons}

(in the Czech Republic the municipality Rokytnice bankrupted in late nineties). As the reaction, central governments set tighter budgetary rules.

However, according to Aristovnik and Bercic (2006) the sustainability of local finance in CEE region is relatively high and only Slovenia and Hungary face limited problems from this point of view. In countries with developed and health banking sector the risk of "over-borrowing" almost disappears.

\section{Public service standards}

As indicated by our question, transfer of responsibilities from the state, organized together with transfer of resources might be connected also with the issue of standards of public services. The issue of standards has more dimensions, and we want to touch on two of them:

- standards, defining the structure and scale of public services to be delivered (service standards),

- standards, defining the quality of public services to be delivered (quality standards).

Concerning the first group, it was for example the Czech Republic that already prepared the system of standards defining the structure and scale of certain public services, as they shall be delivered by local authorities. There is a very different opinion on this, and many experts feel that such approach undermines the principle of local responsibility. The main arguments behind such approach are insufficient information and paternalism (Stiglitz, 1989).

Quality standards are much better accepted, and our feeling is that the system of "Citizen Charters", to provide consumers with criteria to be able to assess what quality they got for their money, shall be further developed in CEE region.

According to our opinion, the central government should focus not so much on service standards (especially in more developed countries), but instead of this it shall promote regular benchmarking and performance audit procedures (decision if to prefer benchmarking or more difficult performance audit shall be case by case decision, depending on the character of a service), and publishing of data obtained. 


\section{Decentralization trends in CEE: selected evidence}

Processes of decentralization and development of local and regional selfgovernments are characterized by large time and scale differences amoung transitional countries in CEE. Some countries enacted a relatively comprehensive package of decentralization measures already in the first half of nineties (Hungary, Poland). Other countries started with the second phase of decentralization much later (for example Slovakia and the Czech Republic in late nineties), and there are countries where massive decentralization started only recently (Macedonia) or is only starting now (Ukraine).

The willingness to decentralize and the scale and timing of decentralization in selected countries are to some extend demonstrated by the Table 3 showing the formal willingness of CEE countries to decentralize.

As obvious, all CEE countries promised to create real local selfgovernments; however the real level of respecting all signed principles still differs (seems that the most "out of date" country is Ukraine, where elected local governments do not have any own funds).

The scale of responsibilities delegated to municipalities differs significantly between CEE countries and the amount of own resources of elected local units is lower than in "old" EU member states: "Local public government finance decentralization and building the capacity for local revenue rising abilities of local/regional self-governments reforms have been lagging behind all other reforms in CEE countries" (Sevic, 2005, p. 17). In most CEE countries the share of municipal expenditures in total public expenditures is between 10 and $20 \%$ and in some even bellow $10 \%$. Intergovernmental transfers are still the dominant or a very important resource source (Sevic, 2005). This situation improves very slowly, even in some countries the trend is reverse - for example in Hungary the share of local governments expenditures in GDP decreased from $16,5 \%$ in 1993 to $12,8 \%$ in 2000 .

Due to many factors the size of local self-governments in CEE is highly fragmented, and in some countries there are hundreds or thousands of (too) small municipalities (we will come to this issue also later). Davey $(2002$, p. 36) comments to this: "Failure to drive a solution ... (to territorial fragmentation) ... often leaves in the hands of local state administration functions that should be managed by locally accountable bodies". 
Juraj Nemec

Decentralization reforms and their relations to local

democracy and efficiency: CEE lessons

Table 3: European Charter of Local Self-Government: Signatures, Ratification, and Implementation in CEE Countries

\begin{tabular}{|c|c|c|c|}
\hline $\begin{array}{c}\text { Member State of the } \\
\text { Council of Europe }\end{array}$ & Date of signature & Date of ratification & $\begin{array}{c}\text { Date of entry into } \\
\text { force }\end{array}$ \\
\hline Albania & 27. 05. 1998 & 04.04 .2000 & 01. 08. 2000 \\
\hline Armenia & 11. 05. 2001 & 25. 01.2002 & 01. 05. 2002 \\
\hline Azerbaijan & 21. 12. 2001 & 15. 04. 2002 & 01. 08. 2002 \\
\hline $\mathrm{BiH}$ & 12. 07.2002 & 12. 07.2002 & 01.11 .2002 \\
\hline Bulgaria & 03. 10. 1994 & 10. 05. 1995 & 01. 09. 1995 \\
\hline Croatia & 11. 10. 1997 & 11. 10. 1997 & 01. 02. 1998 \\
\hline Czech Republic & 28. 05. 1998 & 07.05 .1999 & 01.09 .1999 \\
\hline Estonia & 04.11 .1993 & 16. 12. 1994 & 01.04 .1995 \\
\hline Georgia & 29. 05. 2002 & 01.12 .2004 & 01.04 .2005 \\
\hline Hungary & 06. 02. 1992 & 21. 03.1994 & 01.07 .1994 \\
\hline Latvia & 05. 12. 1996 & 05. 12. 1996 & 01.04 .1997 \\
\hline Lithuania & 27. 11. 1996 & 22. 06. 1999 & 01. 10. 1999 \\
\hline Moldova & 02.05 .1996 & 02. 10. 1997 & 01.02 .1998 \\
\hline Poland & 19. 02.1993 & 22. 11. 1993 & 01. 03. 1994 \\
\hline Romania & 04. 10. 1994 & 28. 01.1998 & 01.05 .1998 \\
\hline Russia & 28. 02.1996 & 05. 05. 1998 & 01.09 .1998 \\
\hline Serbia & 24. 06. 2005 & - & - \\
\hline Slovakia & 23. 02. 1999 & 01.02 .2000 & 01.06 .2000 \\
\hline Slovenia & 11. 10. 1994 & 15. 11. 1996 & 01. 03. 1997 \\
\hline Macedonia & 14. 06. 1996 & 06. 06. 1997 & 01. 10. 1997 \\
\hline Ukraine & 06. 11. 1996 & 11. 09. 1997 & 01.01 .1998 \\
\hline
\end{tabular}

Source: www.conventions.coe.int 


\section{Juraj Nemec democracy and efficiency: CEE lessons}

\section{Regional self-government}

On regional level the situation is more complicated. In spite NUTS 2 level is necessary for spending of EU finds, few countries created respective elected structures. In some CEE countries regional self-government units do not exist (even in EU member states, like Bulgaria, where six regions were created in 1999 as administrative and not real self-government units). This situation is connected also to unclear EU policy in this area.

The Draft European Charter on Regional Democracy was initiated by the Council of Europe's Congress of Local and Regional Authorities in Europe (CLRAE) in 1997. The original idea behind the Charter was to set out the key principles that should underlie effective regional democracy in Europe, covering areas such as financial autonomy and legislative powers. However, the Charter failed to attract the support of a sufficient majority of Member States at the Ministerial Conferences in Helsinki in 2002 and Budapest in 2005, with disagreements emerging over whether the instrument should be legally binding.

Additionally, in some countries, where regional self-government units were created, their territories are large enough to fulfil criteria for NUTS 2 (Slovakia, Czech Republic), causing increased transactions costs of management of EU funds and complicating execution of other responsibilities. Although this problem has already been well known and named, for example Slovenia wants to do the same as a part of the territorial structure reform package currently in discussion - as clear example of limited capacity of CEE states to learn on mistakes already done by others and to utilize positive reform outcomes from abroad.

\section{Decentralization and the local democracy}

The relation between decentralization and the local democracy is a two dimensional issue. Effective local democracy represents an important precondition for successful decentralization, and successful decentralization supports development of local democracy. In the following part we highlight some aspects of those relations. 


\section{Juraj Nemec \\ Decentralization reforms and their relations to local \\ democracy and efficiency: CEE lessons}

\section{Are citizens prepared for local democracy (participation)?}

According to our opinion citizens in transitional countries are still not well prepared to execute effective control over politicians and bureaucrats (neither on central, nor on local level) - after the long period of former regime no surprise. There is some evidence to support this argument, but also to show that situation is improving in some dimensions. Many, especially older people, still think that the state "donates them its services" and they must be satisfied with any quality provided (for example in Slovakia almost $40 \%$ of citizen preferred the state to the market in 2005).

The ability to control the state via complaints (or even via courts - in Macedonia there is still only one case of a suiting the government for malfunctions) and by effective participation is also limited. Several surveys provide data (and it seems show some, but limited, improvements). For example (Swianiewicz 2001, p. 66) citizen's willingness to participate in public activities in the Czech Republic in 1995 was as follows:

- certainly yes: $11 \%$

- generally yes: $22 \%$

- not yes, not no: $22 \%$

- generally no: $26 \%$

- certainly no: $12 \%$

The LGS (Soos and Zentai, 2005, p. 175) collected data on different forms of political participation, including following five areas - attendance at public demonstrations, petitions, direct meetings with local officials, challenges to local decisions and proposal writing. According to this research, the most frequent case, drafting or sharing of proposals connected with local affairs, is becoming more and more frequent (especially in Poland and Hungary).

According to Soos and Zentai (2005) the direct role of interested citizens, non-governmental organisations (NGOs), and local businesses is seen as much less important than the role of actors with a formal position within the government structure. These community actors seem to be the least important in Bulgaria-the observation is true first of all in the case of NGOs, but it applies to interested citizens as well. Bulgaria is also the only country in which the role of businesses is assessed as higher than that of interested residents. It is also the only one in which the role of NGOs is seen as negligible. Data about participation in local elections are also not very optimistic, significantly bellow 


\section{Juraj Nemec \\ Decentralization reforms and their relations to local democracy and efficiency: CEE lessons}

$50 \%$ and decreasing (see for example Soos and Zentai, 2005). Especially regional self-government elections do not attract citizens to participate (Slovakia 2006 turn-out was about 15\%).

\section{What are the attitudes of elected local politicians?}

For the position and attitudes of local politicians the answers of local mayors to questions of LDI survey in 1997 are symptomatic (Table 4).

Table 4: Goals of Local Government

\begin{tabular}{|l|c|c|c|}
\hline & Czech Republic & Poland & Slovakia \\
\hline Democracy & 61,3 & 54,3 & 71,7 \\
Autonomy & 67,5 & 61,5 & 89,1 \\
Effectiveness & 71,2 & 84,2 & 49,2 \\
\hline
\end{tabular}

Source: Swianiewicz, P., 2001, p. 24

Data provided show that the right for independent decision making is still the most important for local politicians, in many cases serving to small interest groups and not to total population (in Czech Republic 35\%, in Poland 48\%, in Hungary $42 \%$ of respondents think that local mayors serve only to small part of inhabitants and to small interest groups (Swianiewicz, 2001, p. 25). Because all the provided figures are biased (mayors not willing to present real preferences, citizen due to lack of understanding the modern governance) the real situation seems to be quite unsatisfactory.

\section{Citizen trust to self-governments}

The trust of citizen to local governments is still limited, but much higher that to national level structures (Table 5). 
Juraj Nemec

Decentralization reforms and their relations to local

democracy and efficiency: CEE lessons

Table 5: Level of trust of citizen to different institutions in Slovakia (SR) and the Czech Republic (CR)

\begin{tabular}{|l|c|c|c|c|c|c|}
\hline & \multicolumn{2}{|c|}{1995} & \multicolumn{2}{c|}{1998} & \multicolumn{2}{c|}{2000} \\
\cline { 2 - 7 } & SR & CR & SR & CR & SR & CR \\
\hline Local self-governments & 51 & 57 & 50 & 50 & 53 & 60 \\
National council & 30 & 23 & 32 & 18 & 24 & 22 \\
Central government & 32 & 55 & 33 & 42 & 32 & 30 \\
\hline
\end{tabular}

Source: Swianiewicz, ed., 2001, pp. 56, 231

According to Soos and Zentai (2005) the situation is similar, from selected countries only Bulgaria shows a high level of distrust to regions (however, regions are administrative and not self-government unit in Bulgaria). The most trusted democratic institution is frequently the presidency $149.2 \%$ in Estonia, $38.7 \%$ in Poland, and $40.2 \%$ in Bulgaria). The central government is greatly distrusted in most countries, the least trusted institutions are the political parties (distrusted by $30.1 \%$ in Estonia and $53.4 \%$ in Poland), followed by parliament (40.8\% in Poland and 37.3\% in Bulgaria). Municipal self-governments are in between.

\section{Accountability and responsibility}

Accountability and responsibility are partly different issues, but very much inter-linked, therefore we shall deal with them in one bulk, showing that still no level of government in accession countries really respects its role to serve and to account to its stake-holders: especially to citizen. Several examples and data can support this argument.

In CEE local self-governments in many cases still try to avoid most of alternative forms of accountability. Davey $(2002$, p. 39) comments on this: "The greater degree of fiscal decentralisation the greater need for improved systems of accountability. EU accession processes, for example, highlight the need to develop systems of external audit of local government and to restrict indebtedness, measures that are both unpopular and technically demanding".

Compared to central level, step by step improving in reporting to citizen, local authorities still do not fully accept the necessity to be accountable to local 
citizen, and some existing initiatives are more or less formal. There is for example general trend to publish yearly performance reports of public organisations available to citizen that answer many important performance related questions, like the use of resources, goals and their fulfilment, possible improvements. Municipalities in several CEE countries do not follow this positive trend as a rule. Especially economic performance data are still not the data to be shared with citizen. On the other hand web pages, especially pages of larger cities are significantly improving (author's experience, but also for example Spacek, 2006, Kunstelj, Leben and Vintar, 2006, Aadel, 2006), are also more and more serving to accountability principle.

Legal accountability improves too slowly. In Poland corruption started to be really prosecuted from very late nineties, in Slovakia the first lord-mayor was imprisoned for corruption only in 2006 (not because there is no corruption). Accountability and responsibility are still not values - as clearly visible from the statement of the director of one hospital in Slovakia, caught for large inefficiencies in procurement:

"The life of the patient is much more important than the Public Procurement Law. Our only concern is to provide the patient with maximum care". The patient does not care about the procurement of medicaments; he just wants his/her drug" (Správy STV, 3. 11. 2004).

\section{Transparency and corruption}

Mixed experience with some major preconditions of functional decentralised local governance continues also when investigating level of transparency. No surprise - increased transparency limits possibilities for exercising private (non-ethical) benefits from serving in public positions, still common practice in all accession countries. CEE countries still belong to the most corrupted states in the world, at least according to Transparency International corruption perception indexes (Table 6).

The problems of corruption and its sources in selected CEE countries were deeply investigated by Miller, Grodeland and Koschechkina (1998), bringing very interesting results, highlighting important sources of corruption. 
Juraj Nemec

Decentralization reforms and their relations to local

democracy and efficiency: CEE lessons

Table 6: 2005 Corruption Perceptions Index* in selected CEE countries

\begin{tabular}{|c|c|c|}
\hline $\begin{array}{c}\text { Country } \\
\text { rank }\end{array}$ & Country & 2005 CPI Score \\
\hline 1 & Island & 9.7 \\
\hline 2 & Finland & 9.6 \\
\hline 27 & Estonia & 6.4 \\
\hline 31 & Slovenia & 6.1 \\
\hline 40 & Hungary & 5.0 \\
\hline 44 & Lithuania & 4.8 \\
\hline 47 & Czechia & 4.3 \\
\hline 47 & Slovakia & 4.3 \\
\hline 51 & Latvia & 4.2 \\
\hline 55 & Bulgaria & 4.0 \\
\hline 70 & Croatia & 3.4 \\
\hline 70 & Poland & 3.4 \\
\hline 85 & Romania & 3.0 \\
\hline 107 & Ukraine & 2.6 \\
\hline 128 & Russia & 2.4 \\
\hline
\end{tabular}

* 2005 CPI Score relates to perceptions of the degree of corruption as seen by business people, academics and risk analysts, and ranges between 10 (highly clean) and 0 (highly corrupt). Source: www.transparency.sk

The Table 7 indicates that politicians and officials might behave as rent seekers not responsible for promoting national and local interests. 
Table 7: Respondent's view regarding the behaviour of politicians and officials

\begin{tabular}{|l|c|c|c|c|}
\hline & $\begin{array}{c}\text { Czech } \\
\text { Republic }\end{array}$ & Slovakia & Bulgaria & Ukraine \\
\hline $\begin{array}{l}\text { Most politicians behave } \\
\text { worse now } \\
\begin{array}{l}\text { Most officials behave } \\
\text { worse now }\end{array}\end{array}$ & $65 \%$ & $82 \%$ & $40 \%$ & $87 \%$ \\
\hline
\end{tabular}

Source: Miller, Grodeland and Koschechkina (1998)

People seeking something to which they were entitled by law, still feel that they have to offer money or other benefits, to get the service of expected quality. Table 8 highlights this problem.

Table 8: Likelihood that bribes must be offered to different officials

\begin{tabular}{|l|c|c|c|c|}
\hline & Czech Republic & Slovakia & Bulgaria & Ukraine \\
\hline Officials in state ministries & $70 \%$ & $85 \%$ & $82 \%$ & $87 \%$ \\
Hospital doctors & $47 \%$ & $89 \%$ & $93 \%$ & $94 \%$ \\
Customs officials & $53 \%$ & $71 \%$ & $92 \%$ & $86 \%$ \\
Court officials & $44 \%$ & $75 \%$ & $80 \%$ & $87 \%$ \\
MPs & $54 \%$ & $74 \%$ & $74 \%$ & $80 \%$ \\
$\begin{array}{l}\text { University staff } \\
\text { officials in local government }\end{array}$ & $44 \%$ & $78 \%$ & $73 \%$ & $89 \%$ \\
Police officers & $42 \%$ & $58 \%$ & $79 \%$ & $87 \%$ \\
Elected officials on local councils & $44 \%$ & $52 \%$ & $69 \%$ & $80 \%$ \\
$\begin{array}{l}\text { People working in the private } \\
\text { sector } \\
\text { School teachers }\end{array}$ & $42 \%$ & $55 \%$ & $63 \%$ & $61 \%$ \\
\hline
\end{tabular}

Source: Miller, Grodeland and Koschechkina (1998) 


\section{Juraj Nemec \\ Decentralization reforms and their relations to local \\ democracy and efficiency: CEE lessons}

Data provided by Miller, Grodeland and Koschechkina may be seen as outdated, but also current pools and researches do not show major improvements (see for example www.transparency.org and national TI pages).

To increase transparency almost all CEE countries recently adopted modern laws on free access to information, however the experiences of compliance with this law on local level are not fully satisfactory. Administrative, financial and time constraints are used to prevent citizen to access "free" information. E-governance is another tool, serving also for better transparency. The example from one of the most "e-developed" country - Slovenia (Kunstelj, Leben and Vintar, 2006) shows that the importance of e-governance also on local level grows, but improvements are still necessary:

"The results of the supply-side survey show that most administrative bodies are presented on the web with information about their organization and operation. They also offer e-mail communication with citizens. Much downloadable application forms are already available for the procedures in the competence of central government bodies, contrary to the local selfgovernment procedures. Regarding the distribution between central and local government of available e-applications, a similar conclusion can be made but the amount of the e-applications is considerably smaller. E-transactions have not been implemented yet.

On the demand side the survey results show that awareness of egovernment among internet users is surprisingly high, as all of them are aware of at least one functional group of e-government (information, e-mail communication with civil servants, downloadable application forms and public eservices). At first glance, the level of e-government usage is also relatively high, as $83 \%$ of internet users have already used at least one of the abovementioned possibilities; however, only a small amount of the provided information, application forms and e-services has already been used. The same is also true of e-mail communication."

To conclude, we have to stress that probably in all accession countries lack of transparency represents one of main weaknesses, prohibiting to achieve generally accepted standards of local governance and successful fiscal decentralization. 


\section{Decentralization and the local efficiency: general problems and selected example}

Good governance has to be effective, efficient and economical. The relations between decentralization and efficiency of local public administration are very difficult to assess, especially in specific conditions of transitional environment, with very limited database of necessary data. In the following text we first highlight two important problems limiting the economic success of decentralization. Then we present some examples of local inefficiencies, as warning cases.

\subsection{Costs of decentralization process}

All reforms, including decentralization, are always connected with costs that are usually underestimated (for example estimated costs of public administration reform in Slovakia realized in 1996 were 20 billion Sk, a bit less than $10 \%$ of total yearly state budget expenditures, compared to official planned figure on the level close to 3 billion Sk). It is not so simple to find such amount of resources in accession countries, but without them many necessary preconditions for successful decentralization cannot be achieved. Too high "reform realization" costs (direct and indirect) may also overweight future benefits and limit real success of the reform. To cope with this problem some developed (and also CEE) countries established "deregulation agencies", responsible for "ex-ante audit" type of assessment of any government action, able to prevent "unnecessary reforms". However, such approach - real exante audit of full costs and benefits of decisions (impact assessment) has not been effectively implemented in CEE countries, with Slovenia as one of the few examples of positive practice.

\subsection{Economies of scale}

As already indicated, there are important economic and management limits to decentralise several public services and activities. Because of "scaleeconomics" dimension (decreasing unit costs with increasing scale of production), 
Juraj Nemec

Decentralization reforms and their relations to local

democracy and efficiency: CEE lessons

stressed also by the European Charter of Local Self-Government, it is more effective to produce certain services in larger volumes, in order to decrease unit costs and to deliver effective quality. Nevertheless, the processes of decentralisation and of fiscal decentralisation are very negatively influenced by territorial fragmentation, and limited willingness for amalgamation or voluntary inter-municipal co-operation.

Problems concerning territorial structure appear in most countries at least of one level of self-government (local and/or regional), as we have already mentioned in the above text. In former regime also very small settlements were allowed to become autonomous legal units (municipality). After 1989 only few countries, like Bulgaria or Poland, were able to create larger units of local-self government, but other, especially the Czech Republic or Slovakia maintained fragmented territorial structure with large number of really small scale local authorities (curiously, in both countries the number of municipalities increased after 1990 as the outcome of additional separation processes). The problem of the size of municipalities is presented in Table 9.

Table 9: Average size of municipalities in selected CEE countries

\begin{tabular}{|l|c|c|c|}
\hline Country & $\begin{array}{c}\text { \% of municipalities } \\
\text { bellow } 1000 \\
\text { inhabitants }\end{array}$ & $\begin{array}{c}\text { Average population } \\
\text { of municipality }\end{array}$ & $\begin{array}{c}\text { Average area of } \\
\text { municipality (sqm) }\end{array}$ \\
\hline Bulgaria & 0 & 35000 & 432 \\
Poland & 0 & 16000 & 130 \\
Hungary & 54 & 3300 & 32 \\
Slovakia & 68 & 1900 & 17 \\
Czech Republic & 80 & 1700 & 13 \\
\hline
\end{tabular}

Source: Davey, 2002, p. 36

As apparent from respective data many "CEE countries have thousands of communities with municipal status with population bellow 1000 (and a substantial proportion of these fewer than 200). Reform programs are challenged by the inability of such communities to provide administrative 
and financial capacity, and the scale economics and catchment areas necessary for essential services" (Davey, 2002, p. 35).

The problem of fragmentation could be solved by voluntary co-operation, or by contracting, but such mechanisms are still in very early stage of their development in all CEE countries.

\subsection{Local inefficiencies - contracting for local public services in Czechia and Slovakia}

Contracting is a frequent form of delivery of local services. The Table 10 compares the scale of contracting-out in Slovakia and Czech Republic and its development trends.

Table 10: Scale of external forms (contracting out) of delivery of selected local public services in Slovak and Czech municipalities (\%)

\begin{tabular}{|l|c|c|c|c|c|}
\hline \multirow{2}{*}{ Service } & \multicolumn{3}{|c|}{ Slovak Republic } & \multicolumn{2}{c|}{ Czech Republic } \\
\cline { 2 - 6 } & 2001 & 2005 & $2006 \mathrm{TI}$ & 2001 & $2005 \mathrm{TI}$ \\
\hline Waste & 49 & 64 & 69 & 71 & 80 \\
Cemeteries & 27 & 12 & 16 & 42 & 26 \\
Public green & 16 & 18 & 33 & 45 & 24 \\
Communications & 21 & 41 & 45 & 31 & 60 \\
Public lighting & 30 & 35 & 40 & 23 & 38 \\
\hline
\end{tabular}

Source: original research based on the data obtained from selected municipalities related to the local service delivery and in 2001 and 2005 and data gathered from results of research projects of Transparency International Slovakia and Czechia (TI).

According to the data collected external delivery of local public services (excepting maintenance of public lighting infrastructure) was used in medium 


\section{Juraj Nemec \\ Decentralization reforms and their relations to local \\ democracy and efficiency: CEE lessons}

scale in Slovakia already in 2001, and was even more frequent in Czechia. The scale of contracting-out selected local public services by municipalities (excepting management of cemeteries in both countries and public green maintenance in Czechia) has increased apparently in the last period. The data clearly indicate that external delivery of local public services is a very frequent solution both in Slovakia and Czechia.

In theory, the decision to contract (to achieve the "best value") shall be based on careful analysis of all available choices, especially on the systematic assessment of existing alternatives (ex-ante audit). The selection of external supplier shall also respect relevant legislative norms (Medved', Mericková, Nemec, 2004).

However, the ex-ante analysis of the most appropriate form of delivery is not effectively realized in Czech or Slovak municipalities - if nothing else, municipalities do not have data on real costs, allowing comparing. Also, although both countries are already EU members and should respect EU directives and not only national procurement laws, the process of contracting is in most cases non-transparent. The Table 11 presents data on methods of contractingout of selected local public services used by the analyzed municipalities.

Table 11: The use of procurement methods in selection of external suppliers (\%)

\begin{tabular}{|l|c|c|c|c|}
\hline \multirow{2}{*}{ Procurement method used } & \multicolumn{3}{|c|}{ Slovak Republic } & $\begin{array}{c}\text { Czech Re- } \\
\text { public }\end{array}$ \\
\cline { 2 - 5 } & 2001 & 2005 & $2006 \mathrm{TI}$ & 2005 \\
\hline Open procedure & 16 & 17 & 27 & 12 \\
Restricted procedure & 5 & 0 & 5 & 40 \\
Negotiated procedure & 0 & 13 & 30 & - \\
Price bid & 0 & 0 & 0 & - \\
$\begin{array}{l}\text { Direct purchase } \\
\begin{array}{l}\text { Municipality was not willing to } \\
\text { provide information }\end{array}\end{array}$ & 31 & 17 & 38 & 48 \\
\hline
\end{tabular}

Source: Original research based on the data obtained from selected municipalities related to the local service delivery and in 2001 and 2005 and data gathered from results of research projects of Transparency International Slovakia and Czechia. 


\section{Juraj Nemec democracy and efficiency: CEE lessons}

Several problems are evident from the table. Many municipalities in Slovakia were not willing to provide information about the procurement method used, although they were to do this (the law on free access to information). The "willingness of municipalities to provide information" was not a problem in samples collected by the Transparency International, because of the "power" of this body and its capacity to invest more resources to the direct questioning. In both countries the practice in selecting an appropriate procurement method is inappropriate. Open tendering is relatively rare, direct purchase, including the negotiated procedure too frequent. Such situation is alarming; in most cases municipalities do not respect public procurement law. There is no really significant improvement in this area.

Concerning efficiency the unit costs are the simplest benchmark of the efficiency in service delivery. However, to be able to understand the data obtained, we should take into account several factors determining the complexity and character of the data:

1. In some cases we cannot calculate the unit costs. The reason is that, the service extent can be hardly quantified and the unification of service delivery does not exist. There are no official standards of the local public services delivery, we can only assume that the level of quantity and quality of service in different municipalities of the same size group is similar.

2. Another problem is that there is no complexity in monitoring this measure by the local self-government. There is no accrual accountancy at the level of local self-government and no possibility to find the real cost value of service delivery'.

The results of our efficiency benchmark are presented by the Table 12, comparing unit costs of internal delivery with contracted services.

\footnotetext{
1 In case of internal service delivery the accounted service costs are mostly lower than the real costs of service delivery and it contains only the direct costs, because there is no accrual accountancy at the local self-government level in Slovakia. We can consider the data of the costs service delivery realised by the municipal employees, gross - budgetary and netbudgetary organisation of municipality as disvalued.
} 
Juraj Nemec

Decentralization reforms and their relations to local

democracy and efficiency: CEE lessons

Table 12: Efficiency of contracting (internal form $=100 \%$ )

\begin{tabular}{|l|c|c|c|c|}
\hline \multirow{2}{*}{ Service } & \multicolumn{3}{|c|}{ Slovak Republic } & $\begin{array}{c}\text { Czech Re- } \\
\text { public }\end{array}$ \\
\cline { 2 - 5 } & 2001 & 2005 & $2006 \mathrm{TI}$ & 2005 \\
\hline Waste & 94 & 94 & 125 & 137 \\
Cemeteries & 64 & 13 & 67 & 95 \\
Public parks & 82 & 192 & 150 & 86 \\
Communications & 70 & 109 & 119 & 142 \\
Public lighting & 100 & 138 & 128 & 118 \\
\hline
\end{tabular}

Source: Original research based on the data obtained from selected municipalities related to the local service delivery in 2001 and 2005 and data gathered from results of research projects of Transparency International Slovakia and Czechia.

The data presented in Table 12 show very different benchmarking results. Contracting out public services in Slovakia is apparently more cost-intensive than internal delivery of public services in 7 cases, where the index is above $120 \%$. The data show clearly higher cost-efficiency only in 5 (one third) cases. There might be several reasons of this result and we cannot decide for just one of them:

1. Inaccuracy in calculating the real cost of service delivery by the local self-government. As indicated, because there is no accrual accountancy at the level of local self-government and thus no possibility to measure the real costs of service delivery, internal delivery costs are underestimated. This means that in cases where the index for external delivery is bellow $120 \%$, contracting should be cost effective. However, recent experience from last Transparency International Slovakia sample clearly indicates that data provided by municipalities are in some cases (cemeteries in Slovakia in 2005) unreliable.

2. Insufficient supply of public services produced by private sector in territory of municipality or monopoly position of private producer of public service - it creates a situation where inappropriate price for service production is charged by the private partner. 


\section{Decentralization reforms and their Nemec democracy and efficiency: CEE lessons}

3. Different local characteristics, different citizen's requirements for services.

4. Higher quality standard of contracted local public services obtaining is cost-intensive.

5. Inappropriate decision-making process in service delivery arrangement selection and large possibilities for corruption in external service producer selection - there are unprofitable contracts for public sector signed.

\section{Conclusion}

Most if not all experts would agree that decentralisation is important, maybe the most important tool of public administration reform, but also that it does not represent unique "all treating" medicine. Decentralisation has the same character as most of other reform mechanisms - it can bring both positive and negative effects, depending on local conditions, environment and connected complementary measures. In inappropriate environment, or because of implementation failures, decentralisation cannot deliver expected positive improvements as a rule. The opposite might be expected - especially in short term perspective, the decentralisation, not supported by other mechanisms, might deepen many existing problems, opening additional space for many forms of "government failure".

Because of the mentioned facts, the formal introduction of local and regional self-government is only the one of the first steps to the real decentralization of the state, and on the way to modern governance, based on principles, explained for example by the "White Paper" (European Commission, 2001) defining main values of modern governance as openness, participation, accountability, effectiveness and coherence.

In CEE environment, decentralization and fiscal decentralization should be implemented very carefully, and as the complex process. Formal transfer of responsibilities and resources might be not enough to achieve positive outcomes and impacts, especially not in short-term dimension. Without implementation of necessary complementary measures, fiscal decentralization may just represent the transfer of public funds from hands of central bureaucrats to hands of local politicians and bureaucrats, serving their private interests, and not citizens as original "owners" of the resources. Such risk is still very high in the specific environment of CEE countries, where local democracy is still developing, and main values of modern governance, like openness, participation, 


\section{Juraj Nemec \\ Decentralization reforms and their relations to local \\ democracy and efficiency: CEE lessons}

accountability, effectiveness and coherence do not dominate on any public administration level. For reform success, this fact is to be respected, and should respect at least following principles:

1. Decentralization shall be understood as a tool and not as the definite goal.

2. Decentralization is not a simple and one-dimensional strategy, and its outcomes and impacts will differ according to concrete time and environment.

3. To decentralize, opportunity, capacity and preparedness are needed.

4. Decentralization strategies have to take account of all the main involved elements - especially legal, financial, territorial and ownership aspects of the process.

Dr. Juraj Nemec je redni profesor javnih financ in javnega menedžmenta na slovaški univerzi Matej Bel v Banski Bystrici, stalni gostujoči profesor na češki univerzi Masaryk v Brnu ter raziskovalni sodelavec na University of Bath, Velika Britanija. Njegovo akademsko in raziskovalno delovanje je usmerjeno predvsem na javno ekonomiko in javne finance, reformo javne uprave, na politike zdravstvenega varstva, ekonomike in menedžmenta ter javnih naročil. Samostojno ali kot soavtor je izdal preko 200 monografij, strokovnih in znanstvenih člankov $v$ slovaščini, češčini, angleščini in drugih jezikih. Je sourednik dveh knjig s področja javnih financ in javnega menedžmenta, ki sta izšli $v$ založbi združenja NISPAcee in bili prevedeni v nešteto tujih jezikov. 


\section{Bibliography}

- $\quad$ Aadel, L.. (2006): The success and failure of electronic governance. The case of Estonia.

- $\quad$ Allen, R., Tomassi, D., ed. (2001): Managing Public Expenditure. SIGMA OECD, Paris.

- $\quad$ Aristovnik, A., Bercic, B. (2006): Sustainability of general government and local government fiscal balances in selected transition countries.

- $\quad$ Arrow, K. J.(1985): The Economics of Agency. In: Pratt, J. W. - Zeckhauser J.: Principals and Agents: The Structure of Business. Boston: Harvard Business School Press.

- $\quad$ Bailey, S. J. (1995): Public Sector Economics. MacMillan.

- $\quad$ Bailey, S. J.: Local Government Economics: Principles and Practice. MacMillan, 1999

- Bouckaert, G. (2002): Renewing Public Leadership: the Context for Service Delivery Reform. Paper presented at NISPAcee annual conference in Cracow.

- Control and Management Baselines for European Memberships. SIGMA OECD, 1999.

- Coombes, D., Verheijen, T. (ed.) (1997): Public Management Reform: Comparative Experiences from East and West. European Commission.

- Cooper, P. J. (2003): Governing by Contract. Washington D.S.: CQ Press.

- Davey, K. (2002): Decentralisation in CEE Countries: Obstacles and Opportunities. In: Peteri, G. (ed.): Mastering Decentralisation and Public Administration Reforms in CEE. LGI Budapest.

- $\quad$ Endegelbeck, R. M. (2004): Using Metrics to Manage Contractor Performance. Graduate School of Business \& Public Policy at the Naval Postgraduate School. Available on: http://www.acquisitionresearch.org/_files/FY2004/NPS-CM-04-011.pdf.

- $\quad$ Ekonomia a financovanie verejneho sektora. FF UMB Banska Bystrica, 1997.

- $\quad$ Epstein, P. D. (1984): Using Performance Measurement in Local Government. New York: Van Nostrand Reinhold Company Inc.

- $\quad$ Government, Market and the Civic Sector: The Search for Productive Partnerships. NISPAcee conference proceedings, 2001.

- Hamerníková, B., Kubatova, K. (2005): Verejne finance. Eurolex, Praha.

- Horvath, T. M. (ed.) (2000): Decentralisation: Experiments and Reforms. LGI Budapest.

- Kunstelj, M., Leben, A., Vintar, M. (2006): E-government in Slovenia: does supply meet demand? NISPAcee.

- $\quad$ Lane, J. E. (2000): New Public Management. Routledge. 


\section{Juraj Nemec \\ Decentralization reforms and their relations to local \\ democracy and efficiency: CEE lessons}

- Loffler, E. (1999): Defining Quality in Public Administration. Paper for the Session on Quality in Public Administration: Basic Concepts and Comparative Perspective. In: Government, Market and the Civic Sector: The Search for a Productive Partnership. Collection of Studies from International Scientifically Conference. Bratislava: NISPAcee.

- Merickova, B. (2002): Zabezpečovanie verejných služieb verejným a súkromným sektorom. EF UMB Banská Bystrica.

- $\quad$ Miller, V. L. , Grodeland, A. B., Koschechkina, T. Y. (1998): Are the People Victims or Accomplices? LGI Budapest.

- Nemec, J.(2001): Risks of outsourcing in Slovakia. World Bank Transitional Newsletter, Vol. 12, No. 4

- Nemec, J., Bercik, P., Kuklis, P. (2000): Local Governments in Slovakia. In: Horvath, T.M., ed.: Decentralisation: Experiments and Reforms. OSI/LGI Budapest.

- $\quad$ Nemec, J., Wright, G. (ed.) (1997): Public Finance: Theory and Practice in Central European Transition. NISPAcee.

- Nemec, J. (2001): Competitive contracting: Problems and potential in the public sector reform process in CEE. In: Government, Market and the Civic sector: The search for productive partnerships.

- $\quad$ Niskanen, W.A. (1971): Bureaucracy and Representative Government, Aldine.

- Pavel, J. (2006): Jsou „obecni“ firmy pri zajistovani verejnych sluzeb efektivni? Brno: ESF MU, CD rom.

- Pollitt, Ch., Bouckaert, G. (2000): Public Management Reform. Oxford.

- $\quad$ Sevic, Z. (ed). (2005): Fiscal decentralization and grant transfers: a critical perspective. NISPAcee.

- $\quad$ Slovensko 2001. IVO, Bratislava, 2002

- Soos, G., Zentai, V. (2005): Faces of Local Democracy: Comparative Papers from Central and Eastern Europe. LGI.

- $\quad$ Soos, G. (2006): The State of Local Democracy in Central Europe. LGI.

- $\quad$ Spacek, D. (2006): Communication and electronic public administration: Some issues in the context of the Czech system of public administration. NISPAcee.

- $\quad$ Stiglitz, J. E. (1989): Economics of the Public Sector. Norton.

- Swianiewicz, P., ed. (2001): Public Perception of Local Governments. OSI/LGI Budapest.

- Vitek, L., Pubal, K. (2002): Evaluation of the Effectiveness of the Tax Collection - the Case of the Czech Central and Local Governments. Paper presented at NISPAcee annual conference in Cracow, 2002 
Juraj Nemec

Decentralization reforms and their relations to local democracy and efficiency: CEE lessons

- Westerwelt, H.V. (1994): Minimum Size of Municipalites. Coloqium on Size of Municipalities, Budapest.

- www.transparency.org

- www.nispa.sk

- www.coe.int 


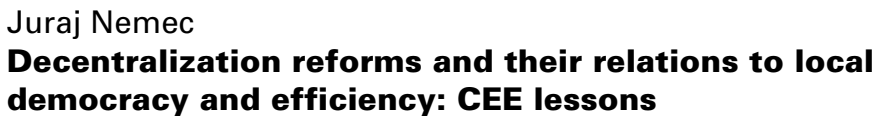

\section{DECENTRALIZACIJSKE REFORME IN NJIHOVA RAZMERJA DO LOKALNE DEMOKRACIJE IN UČINKOVITOSTI: LEKCIJE IZ DRŽAV SREDNJE IN VZHODNE EVROPE}

Prispevek obravnava uvajanje decentralizacije $v$ državah Srednje in Vzhodne Evrope po podpisu in ratifikaciji Evropske listine lokalne samouprave. Nastanek sodobnega in učinkovitega lokalnega ali regionalnega sistema samouprave je na tem področju še vedno ena od glavnih tem reform javne uprave, čeprav so bili osnovni in finančni pogoji za lokalno samoupravo ustvarjeni že zelo zgodaj. Izkušnje in rezultati kažejo, da niso bila izpolnjena vsa pozitivna pričakovanja, ki naj bi jih prinesla decentralizacija in nastanek lokalne samouprave. Nasprotno, pojavili so se specifični problemi, ki se nanašajo na posamezne regije. Verjetno najpomembnejše vprašanje, povezano z decentralizacijo, je načelo subsidiarnosti, ki je jasno izraženo $v$ Evropski listini lokalne samouprave. Javne naloge naj po možnosti izvajajo tiste oblasti, ki so državljanom najbližje. Pričakovati je, da lahko naloge, ki so bližje državljanom, upravljavci bolje razumejo, zaradi česar se lahko tudi bolje odzivajo na posebne lokalne potrebe. $Z$ učinkovitostjo decentralizacije se lahko povečata tudi preglednost in participacija. Vzrok je predvsem $v$ motivaciji, ki izvira iz delegiranja pristojnosti na nižji nivo, ki je bližje "strankam". Decentralizacija lahko pripomore k nastanku sodobnega sistema upravljanja, vendar mora njeno uvajanje spoštovati tudi raven, do katere so bila načela odprtosti, participacije, odgovornosti, učinkovitosti in soodvisnosti že dosežena. Prenos pooblastil z državne ravni s prenosom sredstev je povezan tudi z zagotavljanjem standardov javnih storitev (standardi pri zagotavljanju storitev in standardi zagotavljanja kakovosti).

Vse države podpisnice so se obvezale, da bodo ustvarile lokalno samoupravo. Kljub temu se $v$ resnici vsa načela zelo različno spoštujejo. Stopnja pooblastil, ki so bila prenesena na občine, se zelo razlikuje med državami, nižja so tudi lastna sredstva v primerjavi s "starimi" državami članicami EU. Državni transferji so še vedno prevladujoč ali zelo pomemben vir zagotavljanja sredstev. Kljub pozitivnim rezultatom mora biti decentralizacija vpeljana glede na konkretno okolje, da bi se lahko izognili nepričakovanim negativnim posledicam. Učinkovita demokracija na lokalni ravni je 
pomemben predpogoj za uspešno decentralizacijo, le-ta pa obratno podpira razvoj lokalne demokracije.

Kljub tem ugotovitvam po mnenju avtorja državljani $v$ tranzicijskih državah še vedno niso dobro pripravljeni za izvrševanje učinkovite kontrole nad politiki in uradniki, kar po dolgem obdobju bivših režimov ni veliko presenečenje. $V$ več primerih se pravica do neodvisnega odločanja uporablja $v$ prid majhnim interesnim skupinam in ne celotni populaciji. Dejansko stanje ni zadovoljivo, saj župani niso pripravljeni predstavljati dejanskih prednosti, ki jih prinaša sodobno upravljanje, medtem ko državljanom primanjkuje razumevanje sodobnega upravljanja. Zaupanje državljanov do lokalnih oblasti je še vedno majhno, čeprav je še vedno veliko večje kot do državnih oblastnih struktur. V pristopnih državah nobena raven lokalne samouprave resnično še ne spoštuje svoje vloge do prebivalcev, pravna odgovornost se le počasi izboljšuje; za te države še vedno velja, da so najbolj skorumpirane na celom svetu. $V$ vseh pristopnih državah članicah je verjetno pomanjkanje odprtosti ena največjih slabosti, ki preprečuje doseganje splošno sprejetih standardov lokalne samouprave in uspešne fiskalne decentralizacije.

Negativne posledice decentralizacije se nanašajo na alokacijo finančnih sredstev, optimalizacijo teritorialne strukture in šibkost lokalne demokracije. Enote lokalne uprave, še posebno majhne, niso stroškovno učinkovite niti $v$ upravljanju niti v kakovosti, kakor tudi ne v porabi javnih sredstev. Da bi reforme uresničile načrtovano demokracijo in učinkovitost, bi bilo pri uvajanju decentralizacije treba upoštevati nekatera načela. Vse reforme, tako tudi decentralizacija, so vedno povezane s stroški, ki so navadno podcenjeni, preveliki stroški realizacije pa lahko presegajo prihodnje koristi in omejijo dejanski uspeh reform. Učinki decentralizacije se lahko drastično zmanjšajo z naraščajočim številom decentraliziranih enot. Veliko držav ima skupnosti s statusom občine, $v$ katerih je populacija pod 1000 prebivalcev (znaten del od teh ima manj kot 200 prebivalcev). Reforme so zaradi tega vprašljive, saj take skupnosti ne morejo zagotavljati ustreznih administrativnih in finančnih sposobnosti. Problem razdrobljenosti se lahko reši s prostovoljnim sodelovanjem ali pogodbenim sodelovanjem, vendar so ti mehanizmi $v$ še zelo zgodnji fazi.

Večina strokovnjakov se strinja, da je decentralizacija pomembno, verjetno eno najpomembnejših orodij reform javne uprave, vendar nikakor ne pomeni unikatnega zdravila, ki bi delovalo $v$ vseh primerih. Decentralizacija ima enake značilnosti kot večina drugih reformnih mehanizmov - lahko privede do pozitivnih in negativnih učinkov, ki so odvisni od lokalnih 


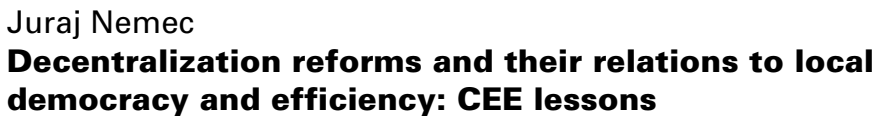

pogojev, okolja in spremljajočih razmerij. $V$ neprimernem okolju ali zaradi napak pri uvajanju decentralizacija ne more zagotoviti pričakovanih pozitivnih izboljšav. Ravno nasprotno - še posebej v kratkoročni perspektivi decentralizacije, ki ni podprta z drugimi mehanizmi - obstoječi problemi se lahko poglobijo in s tem ustvarijo dodatne možnosti za več oblik "vladnega neuspeha". Zaradi omenjenih dejstev je formalna predstavitev lokalne in regionalne samouprave le prvi korak $k$ dejanski decentralizaciji države in na poti k sodobnemu upravljanju, temelječem na načelih, pojasnjenih $\checkmark$ Beli knjigi Evropske Komisije, ki definira glavne vrednote sodobnega upravljanja kot so odprtost, participacija, odgovornost, učinkovitost in koherentnost. V okolju držav Srednje in Vzhodne Evrope morata biti decentralizacija in fiskalna decentralizacija uvedeni zelo pazljivo ter kot kompleksen proces. Formalni prenos odgovornosti in sredstev mogoče ne bo dovolj za pozitivne rezultate. Brez nujnih komplementarnih ukrepov bo fiskalna decentralizacija omogočila le transfer javnih sredstev iz rok centralnih birokratov $v$ roke lokalnih politikov in birokratov, služeč njihovim zasebnim interesom, ne pa državljanom kot prvotnim "lastnikom" sredstev. To tveganje je še vedno zelo veliko $v$ specifičnem okolju držav Srednje in Vzhodne Evrope, kjer se lokalna demokracija še vedno razvija skupaj z glavnimi vrednotami sodobnega upravljanja. Da bi reforme uspele, je treba upoštevati vsaj naslednja pravila: decentralizacija naj bo razumljena le kot orodje in ne kot končni cilj; decentralizacija ni enostavna in enodimenzionalna strategija, njeni rezultati in vplivi se bodo razlikovali glede na čas in okolje; da bi decentralizirali, so potrebne priložnost, sposobnost in pripravljenost; decentralizacijske strategije morajo upoštevati vse glavne vidike, še posebej zakonske, finančne, teritorialne in lastninske vidike tega procesa. 